\title{
PEMBINAAN KESADARAN LINGKUNGAN HIDUP DI PONDOK PESANTREN: STUDI KASUS DI PONDOK PESANTREN AL-MANSUR DARUNNAJAH 3 KABUPATEN SERANG
}

\author{
Ali Muhtarom \\ Institut Agama Islam Negeri (IAIN) Sunan Maulana Hasanuddin Banten \\ Jl. Jend. Sudirman No. 30 Serang, Banten \\ E-mail:alimuhtarom@yahoo.co.id
}

Abstract: This paper discusses the Islamic boarding school respond toward environmental problem and the implementation of Islamic values in environmental awareness development in Al-Mansur Darunnajah 3 Kabupaten Serang, Banten Islamic boarding school. There are three efforts; first, there is an enthusiasm on doing the religious teaching; second, proactive on doing the cleaning; and third, the school concern on developing the eco-Islamic boarding school. There are three kinds of Islamic values implementation; first, intrinstic concern on practising Islamic values; second, creating slogans about prohibition on any kind of environmental damage and throwing rubish, and popularize the motto "bersih, indah, dan aman". The third, there are special rules conducting the environmental problems by giving punishment and organize the schedule for cleaning.

Abstrak: Tulisan ini membahas respon pondok pesantren dalam masalah lingkungan hidup dan cara mengimplementasikan nilai-nilai Islam dalam pembinaan kesadaran lingkungan hidup di Pondok Pesantren Al-Mansur Darunnajah 3 Kabupaten Serang, Banten. Respon pesantren adalah pertama, adanya sikap ant usias dalam melaksanakan ajaran agama. Kedua, sikap proaktif santri dalam melaksanakan tugas kebersihan (piket). Ketiga, kepedulian pesantren dalam mengembangkan program eco-pesantren. Implementasi nilai-nilai Islam dalam pembinaan kesadaran lingkungan hidup adalah pertama, kesadaran intrinsik para santri di dalam mengamalkan nilai-nilai ajaran Islam. Kedua, memasang slogan yang berisi larangan merusak lingkungan dan membuang sampah sembarangan, dan motto pesantren, yaitu "bersih, indah, dan aman. “. Ketiga, adanya at uran tentang lingkungan, yaitu piket kebersihan dan memberlakukan sanksi.

Kata Kunci: Nilai Islam, Pesantren, Pembinaan Kesadaran, Lingkungan Hidup, dan Serang. 


\section{A. Pendahuluan}

Komitmen pesantren dalam menamkan nilai-nilai ajaran Islam direalisasikan dengan berbagai macam bentuk pelayanan keagamaan, seperti mengadakan pembimbingan konseling pada remaja, memberikan penyuluhan pada masyarakat, mengatasi permasalahan dalam rumah tangga, dan berbagai macam penanaman nilai-nilai yang terkandung dalam ajaran Islam. Pesantren terlibat aktif dalam pengkajian keagamaan dan pola-pola sejenis yang dikembangkan dimasyarakat. Kegiatan pesantren ini merupakan benih sangat potensial dalam upaya pengembangan dan pemberdayaan masyarakat. Peran aktif pesantren tersebut tampak jelas pada akhir dasawarsa 70 -an dan dekade 80 -an di mana peran pesantren terlibat secara langsung dalam kegiatan yang lebih substansial dan memfokuskan diri pada kebutuhan riil masyarakat, seperti pengembangan ekonomi, pelestarian lingkungan, dan penggunaan teknologi alternatif (A'la, 2006: 3-4).

Dengan keterbukaan peran pesantren terhdap dunia luar sebagaimana dijelaskan di atas, menunjukkan bahwa pesantren tidak kaku dalam menyikapi berbagai persoalan di masyarakat. Beberapa persoalan yang dihadapi sekarang adalah masalah kerusakan lingkungan, di mana dalam ajaran Islam pun pernasalahan lingkungan juga mendapat perhatian sangat serius. Berbagai program kegiatan di pesantren Al-Mansur Darunnajah 3 ini merupakan wujud manifstasi dari visi dan misi yang telah dibuat pesantren. Visi pesantren AlMansur Darunnajah 3 adalah " mencetak manusia yang muttafaqih fi al-din untuk menjadi kader pemimpin umat/Bangsa dan mendidik kader-kader ummat dan bangsa; yang bertafaqqih fi al-dīn, para ulama', zuamā', dan aghniyä'; cendekiawan muslim yang bertaqwa, berakhlaq mulia, berpengetahuan luas, jasmani yang sehat, terampil dan ulet. Adapun misi pondok pesantren AlMansur Darunnajah 3 adalah pertama, "mencetak manusia yang; beriman dan bertaqwa, berakhlaq mulia, berpengetahuan luas, sehat dan kuat, Trampil dan ulet, mandiri, mampu bersaing, kritis, problem solver, jujur, komunikatif dan berjiwa juang. Kedua. merintis dan mempelopori berdirinya pondok pesantren di seluruh Indonesia sebagai lembaga sosial keagamaan yang bergerak di bidang pendidikan dan dakwah (Darunnajah, 2014). Secara langsung, visi dan misi pondok pesantren Al-Mansur Darunnajah 3 tersebut tidak berhubungan dengan program lingkungan, di dalamnya menampilakan program secara umum, namun jika di dalami persoalan lingkungan juga masuk dalam visi dan misi tersebut. 
Tulisan ini berusaha untuk: pertama menjawab bagaimana respon pondok pesantren Al-Mansur Darunnajah 3 Kabupaten Serang Banten terhadap masalah lingkungan. Kedua, menjawab bagaimana cara mengimplementasikan nilainilai Islam di pondok pesantren Al-Mansur Darunnajah 3 Kabupaten Serang Banten.

\section{B. Budaya Pondok Pesantren Al-Mansur Darunnajah 3 dalam Pengembangan Kesadaran Lingkungan}

Permasalahan lingkungan seharusnya menjadi perhatian penting bagi seluruh manusia sebagai khalifah Allah di bumi karena lingkungan merupakan kelangsungan hidup (manusia dan alam). Melestarikan lingkungan sama maknanya dengan menjamin kelangsungan hidup manusia dan segala yang ada di alam dan sekitarnya. Sebaliknya, merusak lingkungan hidup, apapun bentuknya, merupakan ancaman serius bagi kelangsungan hidup alam dan segala isinya, tidak terkecuali manusia. Pada kenyataannya, masih banyak masyarakat yang belum menyadari dan mereka sering memperlakukan alam dengan semena-mena. Sebagian masyarakat tersebut sering mengabaikan akibat buruk dari berbagai tindakan yang mereka lakukan tanpa menyadari bahwa apa yang mereka lakukan akan berdampak pada kerusakan lingkungan. Adanya keinginan untuk mengeruk hasil dari alam sekitar menjadi motif penting dari sebagian masyarakat untuk mengeksploitasi dan merusak alam sekitar. Hal demikian juga terjadi di wilayah Banten, bahwa masih banyak terdapat lahan dan perkebunan yang diubah menjadi ladang industri, adanya penambangan liar dan penebangan hut an secara liar, sebagaimana yang disampaikan oleh ketua bagian pertamanan dan lingkungan santri.

"Kerusakan lingkungan, khususnya di Banten semakin parah. Karena banyak lahan perkebunan atau hutan-hutan yang dirubah menjadi industri atau pemukiman, lebih khusus lagi di daerah Pabuaran banyak hutan-hutan kecil yang dijadikan ladang mengumpulkan harta kekayaan dan itu sangat merugikan masyarakat sekitar karena itu menyebabkan polusi udara, sungai besar yang kering dan tanah gundul" (Wawancara, ustaz M. Eris Wasahua).

Tidak adanya kepedulian terhadap kesadaran lingkungan hidup juga disebabkankan minimnya pengetahuan yang dimiliki oleh sebagian masyarakat terhadap pelestarian lingkungan hidup. Hal ini sebagaimana disampaikan oleh ketua bidang eksternal pondok pesantren Al-Mansur Darunnajah 3 ustaz M. Eris Wasahua sebaagai berikut:

"Kerusakan lingkungan yang ada di Banten pada saat ini diakibatkan kurangnya kepedulian dari masyarakat terhadap pelestarian lingkungan dan saya 
rasa kurangnya pendidikan terhadap pelestarian lingkungan hidup yang akan menjadikan Banten bersih, indah dan sehat" (wawancara, ustaz M. Eris Wasahua).

Islam mengajarkan kepada umat manusia untuk selalu menjaga kelestarian lingkungan hidup dan mengajak kepada manusia untuk hidup berdampingan selaras dengan alam sekitar. Banyak dalil dari al-Qur'an maupun hadis yang menjelaskan tentang pelestarian lingkungan hidup dan larangan merusak keberadaan lingkungan sekitar. Seperti Firman Allah dalam QS. 42: 30,

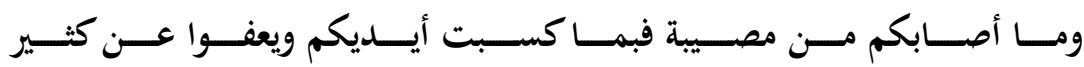

"Dan apa saja musibah yang menimpa kamu maka adalah disebabkan perbuatan tanganmu sendiri, dan Allah memaafkan sebagian besar (dari kesalahan-kesalahanmu)" (Departemen Agama RI, 1989: 788).

Kemudian pada surat surat Ruum: 41 ,

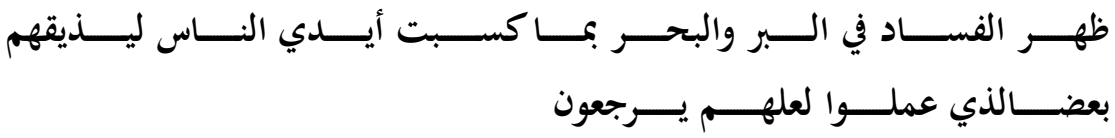

"Telah tampak kerusakan di darat dan di laut disebabkan karena perbuatan tangan manusia, supaya Allah merasakan kepada mereka sebahagian dari (akibat) perbuatan mereka, agar mereka kembali (ke jalan yang benar)" (Departemen Agama RI, 1989: 647).

Selain firman Allah, di dalam hadis Nabi juga dijelaskan nilai-nilai Islam pentingnya menjaga dan melestarikan lingkungan, seperti hadis berikut:

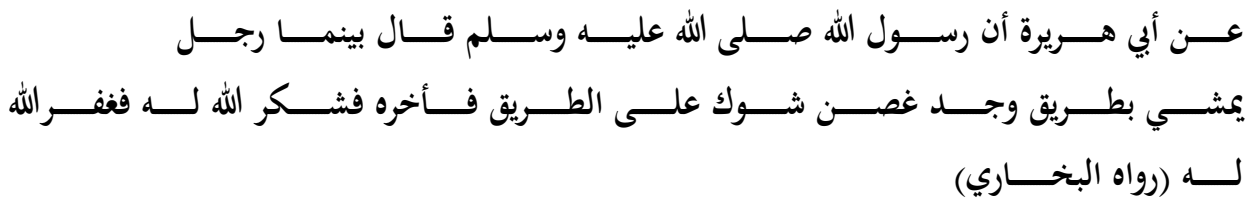

Dari Abu Hurairah: "Sesungguhnya Rasulullah s.a.w. bersabda: "Pada ketika seorang laki-laki berjalan di satu jalan didapatnya sepotong duri terletak di jalan, lalu dibuangkannya. Allah berterima kasih kepadanya, lantas diampuni Allah dosanya". (HR. Bukhari). (Bukhari, et.al, 1969: 185).

Kemudian dalam hadis lain disebutkan tentang kepedulian Islam terhadap lingkungan sebagaimana sabda Nabi berikut:

"Seorang wanita diazab karena seekor kucing yang ia kurung hingga mati, maka ia masuk neraka karenanya. Ia tidak memberinya makan dan minum sewaktu mengurungnya, dan tidak pula melepaskannya agar dapat memakan binatang-binatang melata di bumi” (H.R. Muslim) (Muslim, tt.: 298). 
Adanya nilai normatif ajaran Islam sebagai sebuah doktrin secara tegas melarang kepada umat manusia untuk merusak lingkungan sudah sering di sampaikan oleh para ustaz dalam pengajian-pengajian.

Berbagai upaya untuk menanamkan nilai-nilai ajaran Islam tentang kepedulian terhadap lingkungan sekitar pesantren, khususnya dalam menyadarkan pada semua santri supaya selalu mengingat doktrin ajaran agama tersebut ada beberapa ayat al-Qur'an yang sengaja dipasang sebagai pengingat betapa menjaga lingkungan dan kelestariannya sangat penting. Seperti pada surat. Al-A'raf [7]: 85 yang dipasang di samping aula utama pesantren:

Dan janganlah kamu membuat kerusakan di muka bumi sesudah Tuhan memperbaikinya. Yang demikian itu lebih baik bagimu jika betul-betul kamu orang-orang yang beriman (QS. al-A'raf [7]: 85)

Jika dipahami secara mendalam, ayat tersebut secara tegas melarang secara umum kepada seluruh umat manusia, dan secara khusus kepada seluruh santri di pesantren, membuat kerusakan atau merusak lingkungan yang telah dibuat dan diperbaiki oleh Allah SWT. Doktrin tersebut sekaligus memberikan perintah kepada umat manusia untuk menjaga dan merawat lingkungan yang telah dibuat oleh Allah dengan baik dan penuh tanggung jawab.

Kemudian, dalam pemanfaatan alam, di dalam ajaran Islam juga dijelaskan secara tegas. Sebagaimana firman Allah dalam QS. Luqman [31] ayat 20:

"Tidakkah kamu perhatikan sesungguhnya Allah telah menundukkan untuk (kepentingan) mu apa yang ada di langit dan apa yang ada di bumi dan menyempurnakan untukmu nikmat-Nya lahir dan batin" (QS. Lukman [31]: 20).

Ayat di atas dengan tegas menyatakan bahwa Allah telah memberikan kepada umat manusia segala apa yang ada di langit dan di bumi. Dalam ayat ini terkandung maksud bahwa Allah telah memberikan segala bentuk kenikmatan yang dapat diperoleh seluruh manusia, hanya saja manusia harus bertanggung jawab terhadap semua nikmat yang telah diberikan Allah. Tanggung jawab itu merupakan bentuk syukur atas berbagai nikmat yang telah diberikan Allah. Barang siapa yang mensyukuri nikmat yang telah diberikan Allah, maka Allah akan menambahkan nikmat kepada hamba tersebut, dan sebaliknya, barang siapa yang mensyukuri nikmat yang telah diberikan Allah, yaitu tidak bertanggung terhadap nikmat yang telah diberikan maka mereka termasuk golongan orang-orang yang merugi dan akan mendapat siksanya.

Pemeliharaan lingkungan bukanlah sekadar estetika (keindahan) semata namun lebih pada implementasi tujuan diberlakukannya nilai-nilai ajaran Islam. Yusuf Qardhawi menjelaskan bahwa pemeliharaan lingkungan termasuk dalam 
tujuan pemberlakuan syariah agama (maqāṣid al-syari 'ah) sebagaimana konsepsi Imam Al Syatibi berkaitan tujuan pemberlakuan syariat Islam, yaitu ḥifẓu al- nafs, hifẓu al-aql, hifẓu al-māl, hifẓu al-nasl, dan ḥifẓu a-dỉn (Qardhawi, 2001, 39). Pemahaman yang bisa dicapai adalah pemeliharaan lingkungan sebagaimana ulasan dalam bab ini merupakan penjagaan dan realisasi dari kelima tujuan syariat tersebut. Oleh karena itu, apabila ada manusia yang berbuat kerusakan atau merusak lingkungan, maka dianggap telah melanggar syariat Islam.

Dalam ranah konseptual dan doktrin yang dianut di pondok pesantren AlMansur Darunnajah 3 menganut nilai normatif ajaran Islam yang merupakan tujuan syariat tersebut. Namun yang menjadi menarik adalah bahwa di pondok pesantren Al-Mansur Darunnajah 3 ini dalam menjaga lingkungan sekitar telah menunjukkan adanya respon positif, yaitu adanya spirit dari para santri bahwa dalam melakukan pemeliharaan lingkungan didasari atas keyakinan menjalankan nilai ajaran Islam dengan harapan mendapat ridha dari Allah, di samping itu juga para santri mengikuti perintah kiai yang didasarkan pada sam'an wată'atan, yaitu mengikuti dan menaati apa yang diajarkan.

Menjaga lingkungan termasuk di di dalamnya adalah menjaga kebersihan sangatlah penting, sering kita mendengar ungkapan "Bersih Pangkal Sehat" dari ungkapan tersebut mengandung arti betapa pentingnya kebersihan bagi kesehatan manusia, baik perorangan, keluarga, masyarakat maupun lingkungan. Kebersihan merupakan upaya manusia untuk memelihara diri dan lingkungannya dari segala yang kotor dalam rangka mewujudkan dan melestarikan kehidupan yang nyaman dan sehat. Kebersihan menjadi syarat bagi terciptanya kesehatan, karena sehat merupakan salah satu faktor untuk menuju kebahagiaan. Sebaliknya kotor merupakan penyebab terjadinya penderitaan, karena di samping merusak keindahan, kotor juga dapat menimbulkan berbagai penyakit. Untuk menjadi teladan dalam hidup bersih harus dimulai dari diri sendiri, rumah tangga sendiri dan lingkungan sendiri.

Dalam lingkungan pesantren Al-Mansur Darunnajah 3 hidup bersih tersebut dimulai dari diri masyarakat pesantren sendiri terutama para guru (ustaz) dalam posisinya sebagai pendidik. Sebagaimana ungkapan dari guru yang berarti digugu dan ditiru. Bagaimana anak didik akan meniru gurunya, kalau guru membuang sampah disembarang tempat atau merokok dan membuang puntungnya di mana saja, maka untuk menciptakan lingkungan bersih dalam lingkungan pesantren memandang harus dimulai dari guru sebagai pendidik. Selain keteladanan juga ditarapkan beberapa perat uran yang lebih spesifik untuk ditaati bersama-sama di pesantren. Bentuk kegiatan tersebut adalah: 
Pertama, adanya tata tertib santri dan guru agar menjaga kebersihan lingkungan pesantren. Bentuk dari kegiatannya sendiri yaitu pesantren membuat tata tertib yang isinya bagi semua warga yang tinggal di pesantren wajib melaksanakan dan menjaga lingkungan yang bersih dan sehat.

Kedua, adanya bentuk kegiatan yang disebut dengan piket lingkungan dan jadwal piket. Kegiatan "piket lingkungan" menurut ketua bidang kebersihan dan kesehatan, adalah kegiatan yang dilaksanakan setiap hari, di mana para santri ditugaskan untuk melakukan kegiatan bersih-bersih lingkungan pesantren pada setiap pagi dan sore dan kegiatan bersih lingkungan yang bersifat kolektif, artinya pada setiap seminggu sekali seluruh penghuni pesantren wajib mengikuti kerja bakti dalam rangka membersihkan lingkungan sekitar. Kegiatan piket lingkungan ini sendiri adalah kegiatan bersih-bersih lingkungan sekitar pesantren agar bersih dan nyaman, di samping juga untuk selalu menyiram tanaman yang ada di halaman pesantren agar tetap asri dan indah.

Ketiga, penerapan sanksi bagi warga santri yang tidak melaksanakan dan mendukung terciptanya lingkungan sekolah yang bersih dan sehat. Perilaku yang menunjukkan kearifan lokal juga ditunjukkan oleh para santri di lingkungan pondok yaitu dengan adanya pemeliharaan lingkungan sekitar pesantren dengan menata pertamanan, melakukan kegiatan kerja bakti membersihkan lingkungan, baik dalam bentuk piket, maupun program kerja bakti mingguan.

Salah satu upaya pesantren kami dalam menanggulangi kerusakan lingkungan adalah dengan mengadakan eco-pesantren, yaitu dengan mengadakan kegiatan penanaman pohon (Wawancara dengan Ketua Lingkungan di Pesantren Al-Mansur Darunnajah 3).

Di samping penghayatan dari doktrin ajaran Islam, dalam rangka merespon permasalahan lingkungan di sekitar pesantren, di pesantren Al-Mansur Darunnajah 3 membentuk kesadaran santri yang sudah diwujudkan dalam bentuk selalu menaati peraturan-peraturan yang diterapkan oleh pesantren terkait menjaga dan melestarikan lingkungan sekitar, mengadakan program penghijauan di sekitar pesantren sebagaimana yang dijelaskan di atas, yaitu dengan menumbuhkan kesadaran santri pada kesadarn menanam pohon, atau yang dikenal dengan istilah eco-pesantren.

Program eco-pesantren sebagai model pendidikan lingkungan hidup yang diterapkan di pondok pesantren sudah digagas bersama Kementerian Agama Republik Indonesia pada tanggal 5 sampai tanggal 6 Maret 2008. Eco-pesantren sebagai salah satu bentuk pendidikan lingkungan hidup khas Indonesia berbasis pondok pesantren. Istilah eco-pesantren pertama kali diperkenalkan pada 
pertemuan "moeslem seven year action plan for climate change" di Istambul Turki pada awal Juni 2009.

Secara etimologi, bahasa kata eco-pesantren berasal dari dua kata yang masing-masing mempunyai definisi yang berbeda. Kata eco berasal dari kata "ecology" atau ecosystem yang memiliki erat kaitan dengan lingkungan hidup. Adapun pesantren sebagaimana yang dijelaskan dalam penelitian ini adalah institusi khas Indonesia yang mengajarkan ilmu-ilmu keislaman. Adapun secara definitif eco-pesantren berarti sebuah institusi pendidikan Islam (pesantren) yang mempunyai penekanan pada aktivitas yang tanggap terhadap kelestarian lingkungan hidup.

Dalam kaitannya dengan perhatian terhadap masalah lingkungan hidup, lebih lanjut dijelaskan pula bahwa peran agama sangat penting di dalam memberikan kontribusi dan ikut terlibat secara langsung dalam mencari solusi keluar dari krisis lingkungan. Mengingat gejala yang dilakukan oleh sebagian manusia terhadap alam masih terlihat kurang memperdulikan kelestarian lingkungan. Seorang Guru Besar agama dari Bucknel University, Mery Evlyn Tucker (2003: 85) mengatakan bahwa "agama memiliki lima resep dasar untuk menyelamatkan lingkungan: Pertama, referensi atau keyakinan yang dapat diperoleh dari teks-teks (kitab suci) dan kepercayaan yang mereka (umat manusia) yakini. Kedua, respek, penghargaan kepada semua makhluk hidup yang diajarkan oleh agama sebagai makhluk Tuhan. Ketiga, restain, kemampuan untuk mengelola dan mengontrol sesuatu supaya penggunaannya tidak mubazir. Keempat, redistribustion, kemampuan untuk menyebarkan kekayaan, kegembiraan, dan kebersamaan melalui langkah dermawan, misalnya zakat dan Infak. Kelima, responsibility, sikap bertanggung jawab dalam merawat kondisi lingkungan dan alam sekitar.

Pendapat tersebut sangat sudah sejalan dengan konsep eco-pesantren. Oleh karena itu melalui program eco-pesantren ini diharapkan selain dapat menggugah kesadaran umat Islam untuk lebih memahami dan peduli terhadap kondisi lingkungannya, dan juga diharapkan dapat melakukan penggalian dan pengkajian secara komprehensif tentang konsep Islam yang berkaitan dengan lingkungan serta implementasinya. Dengan bentuk ikhtiar ini akan akan menjadikan pondok pesantren sebagai pusat pembelajaran lingkungan bagi masyarakat. Dengan adanya program eco-pesantren yang dilaksanakan pada pesantren Al-Mansur Darunnajah 3 Kabupaten Serang dengan berbagai macam bentuk kegiatan penanaman pohon, penghijauan, menunjukkan bahwa pesantren Al-Mansur Darunnajah 3 Kabupaten Serang sudah memiliki respon 
positif dalam rangka mewujudkan perannya dalam membentuk kesadaran dan kepedulian pada pelestarian lingkungan hidup. Khususnya di wilayah pesantren.

\section{Islam dalam Pengembangan Kesadaran LingKungan HiduP}

Permasalahan lingkungan yang sering terjadi dilingkungan pesantren adalah persoalan kebersihan, sebagaimana sebagian masyarakat menganggap bahwa pesantren merupakan wilayah yang kumuh dan kurang penjagaan kebersihan. Imej dari sebagian masyarakat tersebut seharusnya tidak perlu muncul karena sebenarnya di dalam lingkungan masyarakat pesantren sudah dibekali dengan nilai-nilai ajaran agama Islam yang sudah melekat sebagai doktrin yang dipegangi dan diyakini oleh semua santri. di samping itu juga, di dalam pesantren sudah diberlakukan program-program dan peraturan-peraturan yang berhubungan dengan kebersihan. Doktrin, program, dan peraturanperat uran tent unya bert ujuan mulia, yaitu untuk mengarahkan kepada semua santri untuk menjaga dan merawat lingkungan sekitar dengan baik dari segi kebersihan dan kebermanfaatannya.

Kepedulian terhadap pelesatrian lingkungan hidup di pesantren juga selalu disampaikan oleh para tokoh agama. Sebagaimana yang disampaikan oleh KH. Busthomi Ibrohim berikut:

"sudah jelas sekali bahwa agama Islam sangat peduli terhadap keberadaan lingkungan, baik itu berkaitan dengan kebersihan, larangan merusak alam dan lingkungan, serta berbagai ancaman bagi orang merusak kelestarian lingkungan. Dalam Islam banyak sekali dali Al Quran maupun Hadis Nabi yang memerintahkan supaya kita melestarikan lingkungan hidup. Seperti ayat ke-41 surat arrum Allah menjelaskan secara tegas bahwa munculnya kerusakan di muka bumi ini memang diakibatkan karena perbuatan manusia itu sendiri" (Wawancara dengan pengasuh pesantren Al-Mansur Darunnajah 3, KH. Busthomi Ibrahim).

Dalam rangka menerapkan nilai-nilai ajaran terhadap pembentukan kesadaran lingkungan, pondok pesantren telah melakukan berbagai upaya, yaitu dengan cara menanamkan nilai-nilai ajaran Islam pada saat pengajian, belajar di kelas, mendatangi langsung ke kamar-kamar santri, memasang sepanduk tentang larangan merusak alam sekitar. Sebagaimana yang disampaikan oleh pengasuh pesantren:

"Dalam rangka menanamkan nilai kesadaran terhadap lingkungan hidup, ada beberapa cara, pertama kami selalu menekankan tentang kesadaran untuk menjaga lingkungan hidup pada semua santri pada setiap kegiatan pengajian, pada saat belajar di sekolah, dan mendatangi langsung ke ruangan sekolah dan 
pondok para santri. kedua, di samping cara pertama, kami juga memberi peringat an dengan memasang sepanduk sebagaimana yang anda lihat terpampang di samping aula ayat yang mengatakan "Laa tufsiduu fil ardhi ba'da ishlahiha (jangan merusak alam ini, merusak bumi ini sesudah ditata sedemikian baik)" (Wawancara dengan pengasuh pesantren Al-Mansur Darunnajah 3, KH. Busthomi Ibrahim).

Upaya yang dilakukan dengan menempelkan slogan-slogan ini apabila dianalisis sesungguhnya adalah sebagai bentuk dari da'wah dengan menggunakan media. Dan memang apabila ditinjau dari isinya, slogan-slogan dari spanduk tersebut substansinya yaitu untuk memperingatkan agar siapa saja tidak membuat kerusakan terlebih kepada lingkungan hidup, sebagaimana yang telah diperintahkan Allah dalam al-Qur'an. Selain upaya menanamkan nilainilai lewat pengajian dan memasang slogan pada sepanduk tentang kepedulian menjaga lingkungan sekitar, lebih lanjut beliau menambahkan bahwa di Pesantren Al-Mansur Darunnajah 3 juga sudah diterapkan beberapa at uran aturan mengenai upaya menjaga lingkungan, khususnya masalah kebersihan lingkungan di sekitar pesantren.

Alhamdulillah, di pesantren Al-Mansur Darunnjah 3 ini memiliki aturan-aturan yang bersifat normatif, yaitu adanya peraturan yang mewajibkan semua santri untuk selalu membuang sampah pada tempatnya, kewajiban kerja bakti setiap hari jumat pagi, dan dilaksanakannya piket kebersihan setiap hari. Mengenai masalah lingkungan, di sini langsung di bawah strukr biro rumah tangga, yaitu bagian pertamanan dan lingkungan" (Wawancara dengan pengasuh pesantren Al-Mansur Darunnajah 3, KH. Busthomi Ibrahim).

Ketua bidang kesehatan dan kebersihan lingkungan pesantren juga menambahkan:

"respon santri terhadap kebersihan lingkungan sangat baik dan mereka memiliki kesadaran diri untuk menjaga kebersihan lingkungan seperti setiap pagi dan sore mereka melaksanakan kerja bersih (piket) bersama-sama di sekeliling pesantren" (Wawancara dengan pengasuh pesantren Al-Mansur Darunnajah 3, KH. Busthomi Ibrahim).

Sebagaimana observasi langsung di lokasi pesantren tampaknya kesadaran santri sudah muncul dengan adanya lingkungan pesantren yang bersih. Sikap kepatuhan pada penyampaian dan aturan pesantren sudah tertanam dalam diri para santri. walaupun secara khusus tidak terdapat program khusus tentang pemeliharaan lingkungan dan juga belum ada kurikulum khusus tentang fikih lingkungan yang dikaji di pesantren, namun dengan penerapan nilai-nilai ajaran Islam dan program pelestarian lingkungan secara umum bisa memberikan pe- 
nyadaran pada santri tentang pentingnya kebersihan dan pelestarian lingkungan sekitar pesantren.

"waktu antum datang kemari, mungkin bisa melihat sendiri kondisi lingkungan pesantren. Dari depan sampai belakang semua kondisi lingkungannya bersih, hamper tidak ada sampah terlihat kan. Nah, saya kira hal tersebut bagian dari bentuk kesadaran santri di dalam mematuhi aturan kebersihan yang diprogramkan oleh pengurus pesantren. Dan saya meyakini hal ini juga bagian dari bentuk aplikasi kesadaran santri terhadap pengamalan nilai-nilai dari ajaran Islam yang selama ini disampaikan oleh para ustaz kepada mereka para santri, bahwa menjaga lingkungan merupakan bagian dari ajaran Islam yang harus diwujudkan dalam bentuk nyata teraplikasikan, tidak hanya sekadar teori saja" (Wawancara dengan pengasuh pesantren Al-Mansur Darunnajah 3, KH. Busthomi Ibrahim).

Pentingnya pemeliharaan lingkungan telah disadari oleh para santri pondok pesantren al-Mansur Darunnajah 3. Dengan kesadaran ini, bisa dikatakan bahwa segala upaya untuk mengatasi krisis lingkungan hidup yang sedang terjadi bukanlah merupakan hal teknis, politik, ekonomi, hukum, dan sosial semata. Hal itu diperlukan upaya penyelesaian dari berbagai perspektif, salah satu hal terpenting adalah melalui perspektif pengamalan nilai-nilai ajaran agama. Perspektif ini diperlukan dalam rangka menjembatani antara etika (perilaku manusia) dengan norma-norma hukum untuk keselamatan manusia. Pertemuan antara perilaku manusia dan norma-norma hukum itu menjadi kesatuan perspektif keilmuan dan paham tersendiri yang berpusat pada antroposentrisme atau paham yang memfokuskan pada tingkah laku manusia dan lingkungan sekitarnya. Hal ini tampak pada upaya dalam mentransformasikan nilai-nilai dan norma tersebut dalam perilaku keseharian santri di pesantren.

Selama peneliti melakukan proses penelitian di pondok pesantren alMansur Darunnajah 3 ini menemukan bahwa perilaku normatif yang ditunjukkan oleh para santri adalah bahwa para santri sudah memiliki kesadaran dalam pemeliharaan lingkungan hidup, yaitu kesadaran penuh terhadap kondisi lingkungan sekitar pesantren dengan menaati aturan-aturan yang telah diterapkan oleh pesantren. Kesadaran terhadap pemeliharaan lingkungan sekitar tersebut merupakan bentuk implementasi dari pengamalan nilai-nilai ajaran Islam terhadap lingkungan yang terbentuk dari budaya yang berkembang di pesantren.

Keberhasilan pelaksanaan pendidikan lingkungan hidup ditentukan oleh kejelasan tujuan atau sasaran yang hendak dicapai. Oleh karena itu, pendidikan mempunyai peranan yang sangat penting dalam kaitannya dengan pengelolaan 
dan pelestarian lingkungan dan sumber daya alam. Pendidikan berusaha mengubah tingkah laku siswa dalam berfikir dan bertindak atau bertingkah laku. Oleh sebab itu, pendidikan harus diarahkan untuk meningkatkan kemampuan manusia dalam mengatasi masalah-masalah yang berkaitan dengan lingkungan serta lebih mampu meningkatkan daya dukung sosial. Hal ini penting untuk mencegah rusaknya struktur sosial. Lembaga pendidikan sebagai lembaga yang bersifat unik, harus dapat meningkatkan toleransi dan empati yang diperlukan dalam menempuh hidup di dunia yang berdesakan ini. Dengan demikian pendidikan dapat menanamkan kepedulian yang lebih dalam pada faktor-faktor lingkungan sehari-hari. Pendidikan lingkungan hidup dilaksanakan pada sistem lembaga pendidikan pesantren, pada dasarnya adalah untuk membentuk rasa tanggung jawab atas keadaan lingkungan, serta bagaimana memantau, memelihara dan memperbaiki lingkungan tersebut.

Sikap dan nilai yang perlu ditanamkan kepada peserta didik dalam proses pendidikan di pesantren Al-Mansur Darunnajah 3 ini dirahkan pada pembinaan kesadaran dan sikap yang yang seimbang dalam menjaga lingkungan hidup, beberapa harapan tersebut menyangkut hal-hal sebagai berikut:

1. Setiap individu/santri di mana saja berada harus memiliki kesadaran bahwa ia adalah anggota dari masyarakat dunia yang harus peduli terhadap lingkungan hidup.

2. Suatu etika baru tentang penggunaan bahan dari sumber alam harus diajarkan kepeda seluruh santri.

3. Sikap yang menekankan pada adanya harmoni dengan alam lingkungan perlu ditanamkan, bukan sikap untuk menaklukkan alam. Oleh sebab itu santri harus diajak untuk merasa bagian dari alam.

4. Setiap orang/santri harus memperhatikan dan bertindak sesuai dengan kepentingan generasi yang akan datang. Mereka harus siap dan bersedia untuk berkorban. Kalau ia hanya memikirkan kepentingan dan keuntungan diri sendiri, krisis lingkungan akan bertambah terus untuk akhirnya menghancurkan kita sendiri.

5. Setiap orang harus mampu menghayati makna hidup di dunia ini sebagai makhluk ciptaan Allah, Tuhan Yang Maha Esa.

Oleh sebab itulah kemudian, secara ringkas sasaran atau target yang ingin dicapai dengan adanya kesadaran terhadap lingkungan hidup adalah pertama, aspekkesadaran, yaitu membuat individu santri agar sadar serta peka terhadap totalit as lingkungan dan permasalahannya.Kedua, pengetahuan, yaitu membekali individu santri dengan pengetahuan dasar mengenai totalitas lingkungan, 
permasalahan serta mempunyai tanggung jawab.Ketiga, sikap: mendorong individu santri agar memiliki nilai-nilai sosial, kepekaan dan kepedulian terhadap lingkungan, serta motivasi untuk partisipasi aktif dalam perlindungan dan peningkatannya. Keempat, keterampilan, yaitu membantu individu santri unt uk meningkatkan keterampilan yang diperlukan dalam memecahkan permasalahan lingkungan hidup. Kelima, partisipasi, yaitu mengembangkan rasa tanggung jawab pada individu santri agar nantinya santri tersebut ke depan mempunyai sikap yang aktif dalam persoalan-persoalan lingkungan.

Dari aspek-aspek tersebut di atas, melalui pembinaan kesadaran terhadap lingkungan hidup diharapkan dapat tumbuh dalam diri para santri kepedulian terhadap lingkungan sekitar. Bahkan lebih jauh lagi aspek-aspek tersebut dapat mendarah daging ke dalam kepribadian para santri melalui program-program yang dilaksanakan oleh pesantren. Artinya dengan adanya pembinaan tersebut, diharapkan ada perubahan tingkah laku para santri setelah mereka mengalami proses pendidikan tadi. Secara lebih operasional, tujuan pendidikan lingkungan hidup yang ingin dicapai di pesantren Al-Mansur Darunnajah 3 ini adalah mendorong para santri agar mengembangkan kebiasaan menjaga kebersihan dirinya dan kebersihan lingkungan keluarga, mengembangkan dasar bertanggung jawab ke arah keserasian, keselarasan, dan keseimbangan antara manusia dan lingkungannya baik lingkungan alam maupun lingkungan sosialnya, mengembangkan dasar pengetahuan, sikap dan perilaku profesional dalam pendayagunaan, pelestarian, dan peningkatan daya dukung sumber daya yang ada. Apabila ditinjau dan dianalisis, harapan ataupun sasaran yang ingin dicapai dengan adanya pembinaan Pendidikan Lingkungan Hidup di pesantren tersebut adalah sesungguhnya sesuai dengan resolusi dari Belgrade International on Environmental Education, yaitu awarenss (kesadaran), knowledge (pengetahuan), attitudes (sikap), skill (keterampilan), dan participation (partisipasi) (Warnadi, Sunarto dan Muchlidawati, 1996: 51).

Adapun untuk mencapai tujuan atau target tersebut, jenis lingkungan hidup yang dikembangkan di pesantren melalui program eco-pesantren, meliputi lingkungan biotic, lingkungan a-biotic, dan lingkungan sosial. Lingkungan biotic adalah lingkungan hidup yang terdiri lingkungan hayati dan hewani, seperti penanaman dan pemeliharaan tumbuh-tumbuhan di sekitar sekolah seperti menanam bibit mangga, membuat apotik hidup dan pembuatan kolam ikan, di samping juga sering mengajak peserta didik untuk melakukan penelitian tentang hewan-hewan seperti serangga dan lain-lainnya yang sekaligus dijadikan sebagai bahan belajar di kelas. Adapun lingkungan a-biotik (lingkungan bersifat tak hidup) adalah lingkungan yang selain lingkungan 
hayati dan hewani, seperti pengelolaan sampah yang dijadikan pupuk kompos, pengelolaan barang-barang bekas yang dijadikan barang yang multi guna dan lain sebagainya. Adapun lingkungan sosial adalah lingkungan hidup yang mempengaruhi kelangsungan perikehidupan dan kesejahteraan manusia serta makhluk lainnya. Atau bisa juga lingkungan sosial adalah wilayah yang merupakan tempat berlangsungnya bermacam-macam interaksi sosial antara berbagai kelompok beserta pranatanya dengan simbol dan nilai serta norma yang sudah mapan, serta terkait dengan lingkungan alam dan lingkungan binaan/ buatan (tata ruang). Adapun lingkungan sosial yang dikembangkan di pesantren ini misalnya mengajak santri untuk lebih peka terhadap masyarakat sekitar.

Oleh karena itu, pengembangan lingkungan sosial ini pada intinya adalah upaya yang dilakukan pesantren dengan mempertimbangkan keterkaitan antara seluruh komponen yang terdapat dalam lingkungan hidup. Apabila digambarkan ke dalam bentuk skematis, pendidikan lingkungan hidup yang dikembangkan di pesantren melalui kegiatan pembinaan kesadaran seperti dijelaskan di atas, adalah sangat sesuai dengan skema yang telah dibuat oleh Jhony Purba (2005:13) sebagai berikut:

\section{Lingkungan hidup itu terdiri :}

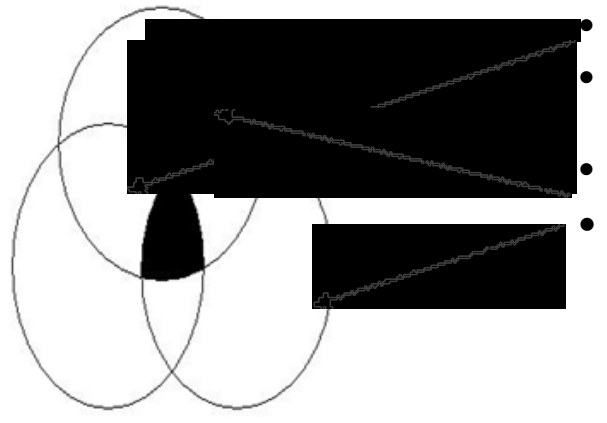

Lingkungan Alam

Lingkungan Binaan/Buatan

(Man Made Environtment)

Lingkungan Sosial

Kesatuan lingkungan hidup manusia dalam kajian pengelolaan lingkungan hidup (wilayah yang dikelola dan berbasiskan ekosistem, tata ruang dan pranata sosial).

Dari gambar di atas dapat dilihat bahwa kesinambungan kehidupan dalam lingkungan sosial tercipta karena keberhasilan interaksi-interaksi manusia dengan lingkungan alami: memanfaatkan sumber daya alam untuk hidup, menciptakan berbagai kemudahan dengan memodifikasi lingkungan alam menjadi habitat-habitat nyaman. Aktivitas-aktivitas ini kemudian menciptakan lingkungan buatan manusia (man made) atau lingkungan binaan. Keberhasilan interaksi dengan lingkungan alami saja tidaklah cukup sehingga perlu juga keberhasilan dalam hubungan-hubungan antara manusia dengan lembaga dan pranata sosial, budaya serta agama. Dalam konteks inilah, muncul konsepkonsep seperti ketahanan sosial misalnya, ialah kemampuan suatu masyarakat 
unt uk hidup sesuai dengan daya dukung dan daya tampung sosialnya disertai dengan kemampuan untuk memulihkan dirinya setelah mengalami bencana (alam, maupun disintegrasi kemasyarakatan). Daya dukung sosial menjadi kemampuan suatu wilayah atau suatu ekosistem untuk mendukung terjaminnya kelangsungan hidup suatu kelompok masyarakat dan keserasian (keharmonisan) antar warganya. Sementara daya tampung sosial merupakan kemampuan manusia dan kelompok penduduk yang berbeda-beda untuk hidup bersamasama sebagai satu masyarakat secara serasi, selaras, seimbang, rukun, tertib, dan aman.

\section{Penutup}

Respon pondok pesantren Al-Mansur Darunnajah 3 terhadap masalah lingkungan menekankan pada pada aturan-aturan yang diterapkan pesantren. Kemudian dari penerapan aspek kearifan lokal diwujudkan dengan adanya spirit para santri bahwa ketika melakukan pemeliharaan lingkungan muncul pemahaman dan keyakinan menjalankan nilai syariah Islam. Respon tersebut adalah, pertama, Sikap ant usias dalam melaksanakan ajaran agama. Kedua, Sikap proaktif santri dalam melaksanakan tugas kebersihan (piket). Sikap aktif dalam menjalankan perat uran dalam bidang kebersihan tampak jelas terlihat dari kekompakan mereka dalam kerja bakti. Ketiga, kepedulian pesantren dalam mengembangkan program eco-pesantren, yaitu program penanaman pohon. Program eco-pesantren ini merupakan bagian dari program penghijauan yang digalakkan oleh kementerian lingkungan hidup.

Adapun implementasi nilai-nilai Islam dalam pembinaan kesadaran lingkungan hidup di pesantren al-Mansur Darunnajah 3 bisa terlihat dari empat hal. Pertama, kesadaran intrinsik para santri di dalam mengamalkan nilai-nilai ajaran Islam. Sebagaimana penjelasan di atas bahwa pemeliharaan kesadaran lingkungan hidup didasarkan pada nilai tujuan syariat (al-maqạșid al-syari' 'ah) yaitu hifẓu al-nafs (memelihara jiwa), hifẓu al-'aql (memeliharan akal), hifẓu almal (memelihara properti), ḥifźu al-nasl (memelihara keturunan), dan hịf̣̣u aldin (memelihara agama). Kedua, Selain wujud kesadaran intrinsik, bentuk implementasi dalam pembinaan kesadaran lingkungan hidup di pesantren diwujudkan dengan upaya memasang sepanduk yang berisi tentang tulisan AlQuran, larangan membuang sampah sembarangan, dan motto pesantren, yaitu "bersih, indah, dan aman. "Ketiga, bentuk implementasi lain yang di terapkan di pesantren dalam pembinaan kesadaran lingkungan sekitar adalah dengan membentuk aturan normatif pesantren, yaitu at uran khusus yang mengurusi persoalan lingkungan. 


\section{Daftar Pustaka}

A'la, Abd. 2002. Pembaharuan Pesantren. Yogyakarta: LKiS.

Ahmadi, Abu dan Uhbiyati, Nur. 2001. Ilmu Pendidikan. Jakarta: Rineka Cipta. Al-Qardhawi, Yusuf. 2002. Islam Agama Ramah Lingkungan (Ri'ayatul alBaiatu fi Syari'ati al-Islami) diterj. Abdullah Hakam Syah. Jakarta: Pustaka Al-Kautsar.

Darunajah. 2014. "Dokumentasi Pondok Pesantren Al-Mansur Darunnajah 3 Kabupaten Serang". Tidak Diterbitkan.

Departemen Agama RI. 1989. Al Quran Dan Terjemahnya, Edisi Baru Revisi Terjemah 1989. Semarang: Toha Putra.

Departemen Pendidikan Nasional. 2007. Menuju Sekolah Berwawasan Lingkungan. Jakarta: Direktorat Jenderal Manajemen Pendidikan Dasar dan Menengah.

Ghazali, M. Bahri. 1996. Lingkungan Hidup dalam Pemahaman Islam, Jakarta: Pedoman Ilmu Jaya.

Harjasoemantri, Koesnadi. 1990. "Pokok-pokok Masalah Lingkungan”, Siti Zawimah dan Nasruddin Harahap (Ed.), Masalah Kependudukan dan Lingkungan Hidup: Di Mana Visi Islam? Yogyakarta: P3M IAIN Sunan Kalijaga.

Idi, Abdullah, dan Suharto, Toto. 2006. Revitalisasi Pendidikan Islam. Yogyakarta: Tiara Wacana.

Mary Evelyn Tucker dan John A.Grim. 2003. Agama, Filsafat dan Lingkungan Hidup (terj.). Yogyakarta: Kanisius.

Soemarwoto, Otto. 2004. Ekologi, Lingkungan Hidup dan Pembangunan. Jakarta: Djambatan.

Yafie, Ali. 1994. Menggagas Fiqh Sosial dari Soal Lingkungan Hidup,Asuransi, Hingga Ukhuwah. Bandung: Mizan. 